\title{
Frequency of Using Najdi Arabic Words Among Saudi College Male Students
}

\author{
Sayed M. Ismail ${ }^{1}$, Nasser Rashid Alshayhan ${ }^{2}$, Salwa Alwafai ${ }^{3} \&$ Bacem A. Essam $^{4}$ \\ ${ }^{1}$ Assistant Professor of Translation Studies, Prince Sattam Bin Abdulaziz University, Saudi Arabia \\ ${ }^{2}$ Assistant Professor of Arabic Language and Literature, Prince Sattam Bin Abdulaziz University, Saudi Arabia \\ ${ }^{3}$ Assistant Professor of Lingustics and Translation Studies, Department of English-College of Arts, Imam \\ Abdulrahman Bin Faisal University, Al-Baath University (previously), Saudi Arabia \\ ${ }^{4}$ Ain Shams University, Egypt \\ Correspondence: Sayed M. Ismail, Prince Sattam Bin Abdulaziz University, Alkharj Community College. Abu \\ Dajan Street-Al-montzha District. P. O. Box 1866, Alkharj 11942, Riyadh, Saudi Arabia. E-mail: \\ a.ismail@psau.edu.sa
}

Received: December 11, 2018 Accepted: January 15, 2019 Online Published: January 29, 2019

doi:10.5539/ijel.v9n2p24 URL: https://doi.org/10.5539/ijel.v9n2p24

\begin{abstract}
The study of dialects may be subsumed under the very broad rubric of colloquialism which comes at the bottom of the formality versus informality scale. We focus on the Najd dialect perception, as the central dialect in Saudi Arabia, among Saudi male college students. By conducting two experiments, questionnaires and follow-up semi-structured interviews, on 137 male students, user-based frequencies of the topper 50 Najdi words are generated. The second phase aims at semantically categorizing the topper content words so that conclusions can be drawn about the inclination of using Najdi words among the college students. Results show that the categorization of the retrieved 50 Najdi words, according to the part of speech, demonstrates that the most applauded Najdi Arabic words are verbs and adjectives. Synonyms are even retrievable from this method of compilation. Nouns are the most resistant part of speech at the morphological level.
\end{abstract}

Keywords: Najdi Arabic, colloquialism, cultural cognition, language resources, lexicography, sociolinguistics

\section{Introduction}

\subsection{Problem Statement}

The poor resourcing of Arabic language and its dialects, unavailability of competent morphological analyzers and syntactic parsers, specificity of the informal discourse and user-generated content, writing inconsistency of users and the dynamic sociolinguistic shifts are obstacles that impede any synchronic understanding of language dynamics and change. This seems to be true especially for the Najdi dialect; compared to the resources and tools applicable on the standard language variety and to the plethora of the enhanced tools for the Indo-European languages. This study, therefore, addresses such a challenge by introducing a dialectal frequency-based lexicon of Najdi words and their English translation. To validate our proposed lexicon, we investigate the familiarity of 137 Saudi college male students with the collected set of words. This effort aims to answer two questions. First, what are the most frequent Najdi content words according to the Saudi male college students? Second, how accurate is the automatic detection of dialectal vocabulary and of their frequency?

\subsection{Review of Literature}

The psycholinguistic profiling of Najdi dialect is scarcely addressed. Ismail (2017) studied the translation challenges of rendering Najdi proverbs into English. He concluded that the process of translating Najd dialect necessitates understanding the external real world in which a dialectal word lives and articulates because dialect words, and their senses, derive meanings from their cultural realities and from their historical context. Alatawi (2015) analyzed the structural, socio-pragmatic, and psycholinguistic analysis of code switching in Arabic TV programs either monolingually among the major dialects (Najdi, Hejazi, Janubi, Shamali \& Shargiah) or bilingually between Arabic and English. Ingham (1994) introduced a bilingual Najdi Arabic-English lexicon. However, his study lacked rigorous criteria of inclusion. Therefore, the specificity of the generated wordlist, and 
lemmas, was not acceptable. This highlights the significance of studying the Najdi dialect as objectively as possible to define the most frequent words and what they may tell about the original culture. In a similar vessel, lexicographic effort has been recently directed toward compiling frequency-based dictionaries for core Arabic vocabulary (Buckwalter \& Parkinson, 2014) and even for word sketches, collocates and thematic lists of American English (Davies \& Gardner, 2013).

Recently, StimulStat, a frequency-based psycholinguistic resource for Russian, is proposed to include approximately 1.7 million word-forms, lemmatized into 52,000 lemmas. Frequency, length, uniqueness point, orthographic, phonological representations (stress, syllabic structure, phonemic transcription), grammatical features, semantic relations (homonymy, polysemy, synonymy), typical age of acquisition and imageability are all covered. StimulStat was built on three printed dictionaries, of which was a frequency lexicon, and a national corpus (Alexeeva et al., 2018).

Drawing on the organization of the mental lexicon, psychologists and lexicographer studied psychologically realistic models of polysemy and synonymy in compilation of general formal dictionaries (Jorgensen, 1990; Miller et al, 1998; Wilks, 2008) and colloquial lexica (Arenas, 2018; Collins \& Yao, 2018; Essam, 2017; McCrae, 2017).

\section{Theoretical Background}

Other than classical Arabic and modern standard Arabic, there are several dialect groups. The major dialectal groups are the Egyptian, Arabian Peninsula, Maghrebi, Sudanese, Mesopotamian, Levantine, Andalusian dialectal groups. Dialect expressions are informal, temporal, and oral. They are also dynamic, novel, often colorful, and humorous and aim either to establish a social identity for the speaker or to make strong impression upon the hearer (Mattiello, 2009). It is thus intelligible and recognizable for the people who share the geographical borders to speak the same dialect as a means for reflecting the identity of the speakers. Considered ambiguous, figurative and specific, the connotation of dialectal expressions is comprehensible for the people who use such expressions in their day-to-day life. Thus, exclusivity is a major feature of dialectal expressions. Playfulness is a common feature that designates the dialectal expressions. In many cases, the dialectal expressions are figurative, as they use metonymy and pun in communicating their intended messages. Dialectal expressions are creative and innovative. They are fallen under the process of permanent reproduction and reconstruction. Spatial and socioeconomic realities stain Arabic dialectal expressions with totally different connotations from the modern standard Arabic (Holes, 2018). The culture-bound elements refer to items, tools, instruments, proper names, food items related to specific culture and specific time. The problem of translating culture bound elements is threshold (Mattiello, 2009).

Najdi dialect is an oral form of speech, which is transferred across generations through imitation and repetition. It is transferred through folklore and oral forms of poetry, like Nabati poetry. In addition, the names of traditional industries, artifacts, crafts, and cultural heritage are realized in dialects. The formation of dialectal words and expression is time bound as well as cultural bound. That is to say, dialect words rapidly change over time because they derive their meanings and understanding from their surrounding world (Holes, 2018). Since Najd region hosted the capital city of Saudi Arabia, Riyadh, there has been a clear shift in the socio-economic realities of Saudi community. The nomadic communities had been replaced by stable communities living in well-organized and modern cities. That is to say, urbanization prevailed over Najd region. The Saudi government began establishing very modern system of education as modern schools and universities have been built in Saudi Arabia. Multiple dialect words are borrowed from Pakistani, Indian, Bengali and English. Today, Najd region is no longer such an isolated desert land. On the contrary, it has become an international city that attracts people from all over the world. This whole issue has clearly been reflected in being the central dialect in Saudi Arabia.

Some dialect expressions are not clear and incomprehensible, which requires interpreting and understanding them in MSA. Given that the intra-lingual concept of translation is no longer valid for translating dialects, because translators fail to retrieve synonyms for the dialectal terms either in the classical Arabic language or in MSA, lexicographic effort is ushered towards computationally generating and compiling frequency-based specific language resources.

\section{Method}

\subsection{Participant Characteristics}

The participants were voluntarily recruited from Prince Sattam Bin Abdulaziz University at their sophomoric year. They were all male native speakers of Arabic who studied language and translation. The participants were asked to report any tribal affiliation if indicated. The mean age of the students was 19 years (range: 18 to 20). A 
link to the online survey, using Surveymonkey, was shared. Those who did not wish to fill in the electronic form were given printed versions of the questionnaire. After responding to the questionnaire, the volunteering students were interviewed. In the interviews, questions were structured to measure the familiarity of the students with the context of the Najdi Arabic words in which they normally live. Put simply, participants were asked to suggest any sentence they usually hear, which contains the investigated Najdi words. A total of 137 responses were collected.

\subsection{Study Material}

We extracted wordlists from two corpora. The first one, TenTen15, was a ready-made searchable corpus, retrieved from the web, and did include both modern standard Arabic and several dialects. The second corpus was generated from online tweets published by Saudi citizens using API bootstrapping. Wordlists were computationally retrieved and sorted on frequency. A list of the 50 most frequent Najdi words were exported into our questionnaire and were sorted on the ranking of the corpus-driven findings. Both electronic and printed forms of the questionnaire were produced to match the preferences of the respondents.

\subsection{Study Procedures}

This study conducted three experiments. First, we computationally compiled most frequent Najdi content words from general and specific contemporary corpora. The frequency of occurrence of each lemma in the corpus and concordance were also retrieved. Second, a questionnaire, which was composed of a 5-Likert-scale question about the frequency of every Najdi word, was designed and tested on 137 male students. All students were sophomoric Saudi college students. Third, interviews were conducted to investigate the familiarity of the respondents with the studied Najdi words. Statistical $t$-test was calculated to compare the human-based evaluation to the automatic computational compilation.

\section{Results}

In this section, we describe the results of the three experiments we have conducted. For the first experiment, the list of retrieved most frequent Najdi content words and their frequencies are provided. The functional words and non-words were excluded. Table 1 displays the frequency of the usage of the 50 topper Najdi Arabic words (NAW) among the studied population. Translation was rendered according to the concordance of each NAW. The Likert scale, used for respondents to evaluate the frequency of using each NAW, was sorted from the most frequent (daily heard NAW) to the least frequent (rarely heard). Respondents demonstrated familiarity with all the studied NAWs.

Table 1. Frequency of the usage of the 50 topper Najdi Arabic words (NAW) among the studied population

\begin{tabular}{|c|c|c|c|c|c|c|c|}
\hline NAW & $\mathrm{NF}$ & Translation & Daily & MTW & MTM & $\mathrm{OM}$ & Rarely \\
\hline هج & 0.0335 & Escape & 28.5 & 28.5 & 21.2 & 5.7 & 16.1 \\
\hline هك & 0.0089 & Lie & 24.8 & 25.7 & 28.5 & 7.3 & 13.7 \\
\hline تفطن & 0.0096 & Investigate & 22.6 & 22.6 & 21.2 & 15.3 & 18.3 \\
\hline نطل & 0.0065 & Throw & 19 & 19.6 & 21.2 & 11.7 & 28.5 \\
\hline مندس & 0.0063 & concealing & 19 & 19.7 & 19 & 9.5 & 32.8 \\
\hline عنز & 0.0059 & Lean & 25.6 & 24.8 & 15.3 & 16.8 & 17.5 \\
\hline هنيه & 0.0053 & Here & 17.6 & 16.8 & 22.6 & 15.3 & 27.7 \\
\hline زبن & 0.0047 & Lodging & 28.5 & 28.5 & 21.2 & 5.7 & 16.1 \\
\hline نيم & 0.0047 & Sleepy & 24.8 & 24.8 & 22.6 & 6.6 & 21.2 \\
\hline سستم & 0.0034 & System & 28.5 & 28.5 & 27 & 7.3 & 8.7 \\
\hline مارج & 0.0024 & Rotten & 33.6 & 33.6 & 16.8 & 8 & 8 \\
\hline عطن & 0.0020 & Gimme* & 24.8 & 24.8 & 22.6 & 8.8 & 19 \\
\hline خراط & 0.0017 & Liar & 21.9 & 21.9 & 19.7 & 8.8 & 27.7 \\
\hline زنط & 0.0017 & Suffocate & 27 & 27 & 19 & 9.5 & 17.5 \\
\hline ابخص & 0.0015 & Expert & 21.9 & 21.9 & 19 & 10.9 & 26.3 \\
\hline انهج & 0.0015 & Faster & 20.4 & 20.4 & 18.2 & 10.9 & 30.1 \\
\hline غضارة & 0.0014 & Bottle & 21.9 & 21.9 & 19 & 11.7 & 25.5 \\
\hline زمين & 0.0012 & Likely & 23.4 & 23.4 & 21.2 & 13.1 & 18.9 \\
\hline يرطن & 0.0011 & Talk much & 24.8 & 24.8 & 22.6 & 13.1 & 14.7 \\
\hline شرواك & 0.0009 & Like you & 26.3 & 26.3 & 24.1 & 13.9 & 9.4 \\
\hline يهجج & 0.0008 & Escape & 27.7 & 27.7 & 22.6 & 14.6 & 7.4 \\
\hline لقف & 0.0006 & Interfere & 24.1 & 24.1 & 21.9 & 15.3 & 14.6 \\
\hline الميانة & 0.0006 & Sanction & 28.5 & 28.5 & 20.4 & 13.1 & 9.5 \\
\hline
\end{tabular}




\begin{tabular}{|c|c|c|c|c|c|c|c|}
\hline هبيلة & 0.0005 & Insane & 29.2 & 29.2 & 19 & 10.9 & 11.7 \\
\hline هبره & 0.0005 & Mountain & 27.7 & 27.7 & 17.5 & 8.8 & 18.3 \\
\hline برطم & 0.0004 & Lips & 24.1 & 24.1 & 15.3 & 10.2 & 26.3 \\
\hline معصي & 0.0004 & Refuse & 22.6 & 22.6 & 18.2 & 6.6 & 30 \\
\hline متروس & 0.0004 & Stuffed & 24.8 & 24.8 & 19 & 8 & 23.4 \\
\hline مملوحة & 0.0002 & Beautiful & 49 & 19 & 17.5 & 11.3 & 3.2 \\
\hline شقردي & 0.0002 & brave & 24.8 & 24.8 & 16.8 & 7.3 & 26.3 \\
\hline نفج & 0.0002 & Escape & 33.4 & 23.4 & 13.1 & 8 & 22.1 \\
\hline لحجي & 0.0002 & Peasant & 27.7 & 27.7 & 10.2 & 8.8 & 25.6 \\
\hline مصرقع & 0.0002 & Reckless & 24.8 & 24.8 & 9.5 & 13.1 & 27.8 \\
\hline مطنوخ & 0.0002 & Rich & 28.5 & 28.5 & 8.8 & 9.5 & 24.7 \\
\hline مشتط & 0.0001 & Angry & 39 & 19 & 10.9 & 13.1 & 18 \\
\hline 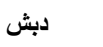 & 0.0001 & Cow & 26.3 & 26.3 & 13.9 & 10.9 & 22.6 \\
\hline كخة & 0.0001 & Dummy & 21.2 & 21.2 & 16.8 & 10.9 & 29.9 \\
\hline سبهه & 0.0001 & Insane & 20.4 & 20.4 & 19.7 & 5.8 & 33.7 \\
\hline دوشق & 0.0001 & Mattress & 21.2 & 21.2 & 22.6 & 5.8 & 29.2 \\
\hline سرويس & 0.0001 & Plate & 49 & 19 & 13.9 & 5.8 & 12.3 \\
\hline هجولة & 0.0001 & Gaudy & 41.2 & 21.2 & 13.1 & 5.8 & 18.7 \\
\hline يهوجس & 0.0001 & Think & 42.6 & 22.6 & 12.4 & 5.8 & 16.6 \\
\hline قروشة & 0.0001 & Troubling & 34.1 & 24.1 & 10.9 & 5.8 & 25.1 \\
\hline ملجلج & 0.0001 & Upsetting & 25.5 & 25.5 & 10.9 & 5.8 & 32.3 \\
\hline يحتري & 0.0001 & Wait & 27 & 27 & 10.2 & 5.8 & 30 \\
\hline هقوة & 0.00001 & Believe & 28.5 & 28.5 & 11.7 & 5.8 & 25.5 \\
\hline ازبن & 0.00001 & Conceal & 30.7 & 30.7 & 13.9 & 5.8 & 18.9 \\
\hline يسعبل & 0.00001 & Droll & 31.4 & 31.4 & 15.3 & 5.8 & 16.1 \\
\hline 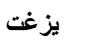 & 0.00001 & Gormandize & 25.5 & 25.5 & 19.7 & 10.9 & 18.4 \\
\hline يكمخ & 0.00001 & Hit & 28.5 & 28.5 & 21.2 & 5.8 & 16 \\
\hline بريعصي & 0.00001 & Lizard & 24.8 & 24.8 & 28.5 & 7.3 & 14.6 \\
\hline مطرسة & 0.00001 & $\operatorname{mix}$ & 22.6 & 22.6 & 21.2 & 15.3 & 18.3 \\
\hline مطاريس & 0.00001 & Mixture & 29 & 19 & 21.2 & 11.7 & 19.1 \\
\hline مفصخ & 0.00001 & Naked & 29 & 18 & 19 & 10.5 & 23.5 \\
\hline قرمبع & 0.00001 & Relic & 24.8 & 24.8 & 15.3 & 16.8 & 18.3 \\
\hline يويق & 0.00001 & Disregard & 16.8 & 16.8 & 22.6 & 15.3 & 28.5 \\
\hline طوفرية & 0.00001 & Plate- tray & 28.5 & 28.5 & 21.2 & 5.8 & 16 \\
\hline مزلب & 0.00001 & Reckless & 24.8 & 24.8 & 22.6 & 6.6 & 21.2 \\
\hline ذ ذعرتني & 0.00001 & Scared & 28.5 & 28.5 & 27 & 7.3 & 8.7 \\
\hline منجطل & 0.00001 & Side-sleeping & 33.6 & 33.6 & 16.8 & 8 & 8 \\
\hline يتتن & 0.00001 & Smoke & 24.8 & 24.8 & 22.6 & 8.8 & 19 \\
\hline مردغة & 0.00001 & Stroke & 21.9 & 21.9 & 19.7 & 8.8 & 27.7 \\
\hline يزوزي & 0.00001 & Whisper & 27 & 27 & 19 & 9.5 & 17.5 \\
\hline
\end{tabular}

Note. Abbreviations: MTW: Multiple times weekly; MTM: Multiple times monthly; NF: Normalized Frequency; OM: Once monthly. * Short form for "give me".

The categorization of the studied 50 Najdi words, according to the part of speech, demonstrates that the most applauded NAWs are verbs and adjectives. Synonyms are even retrievable from this method of compilation (e.g.,

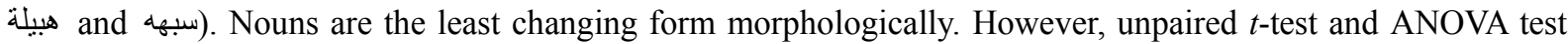
revealed a statistical significance between the frequencies retrieved computationally and the frequencies scored by the students. Post-hoc Tukey test showed that verbs and adjectives were of greater familiarity to respondents than of what numbers predicted. 
Table 2. Frequency of the usage of the 50 topper Najdi Arabic words (NAW) among the studied population

\begin{tabular}{|c|c|c|c|c|c|c|c|}
\hline Verbs & & Adjectives & & Nouns & & Adverbs & \\
\hline هج & Escape & مندس & concealing & زبن & Lodging & هنيه & Here \\
\hline هك & Lie & نيم & Sleepy & ستتم & System & زمين & Likely \\
\hline تفطن & Investigate & مارج & Rotten & ابخص & Expert & منجطل & Side-sleeping \\
\hline نطل & Throw & خراط & Liar & غضارة & Bottle & & \\
\hline عنز & Lean & انهج & Faster & الميانة & Sanction & & \\
\hline عطن & Gimme & يرطن & Talkative & هبره & Mountain & & \\
\hline زنط & Suffocate & شرو اك & Like you & برطم & Lips & & \\
\hline يهج & Escape & هبيلة & Insane & لحجي & Peasant & & \\
\hline لقف & Interfere & متروس & Stuffed & دبش" & Cow & & \\
\hline معصي & Refuse & مملوحة & Beautiful & دوشق & Mattress & & \\
\hline نفج & Escape & شقردي & brave & سرويس & Plate & & \\
\hline يهوجس & Think & مصرقع & Reckless & بريعصي & Lizard & & \\
\hline يحتري & Wait & مطنوخ & Rich & مطاريس" & Mixture & & \\
\hline هقوة & Believe & مشتط & Angry & قرمبع & Relic & & \\
\hline ازبن & Conceal & كمخة & Dummy & طوفرية & Plate/tray & & \\
\hline يسعبل & Droll & سبهه & Insane & & & & \\
\hline بز غت & Gormandize & هجولة & Gaudy & & & & \\
\hline يكمخ & Hit & قروشة & Troubling & & & & \\
\hline مطرسة & $\operatorname{mix}$ & ملجلج & Upsetting & & & & \\
\hline يويق & Disregard & مفصخ & Naked & & & & \\
\hline يتتن & Smoke & مزلب & Reckless & & & & \\
\hline مردغة & Stroke & ذعرتني & Scared & & & & \\
\hline بزوزي & Whisper & & & & & & \\
\hline
\end{tabular}

\section{Discussion}

Dialect expressions are often informal, temporal, and dynamic. They are used for establishing a social identity or for making strong impression upon the hearer (Mattiello, 2009). Najdi dialect is an oral form of speech, which is transferred across generations through imitation and repetition. It is transferred through folklore and oral forms of poetry, like Nabati poetry. In addition, the names of traditional industries, artifacts, crafts, and cultural heritage are realized in dialects. Notwithstanding, some dialect expressions are not clear and incomprehensible, which requires interpreting and understanding them in MSA. Psycholinguistic lexicographic effort is ushered towards computationally generating and compiling frequency-based specific lexicon for addressing the most frequent Najdi dialect expressions.

In our proposed lexicon, we excluded the functional words because they are systematically used in all languages. Therefore, the incidence of its use is not of paramount importance, unlike the content words. The majority of content words denote thematically motion verbs, size description, emotion regulation and culture-specific designations. The results retrieved from Hanson et al. (2001) go semantically hand in hand with our results. Such result reported a greater predilection of frequently using words which express activities, persons (patients and agents) and the products of human activities.

To the best of our knowledge, this is the first study which aims at compiling a frequency-based Najdi Arabic-English lexicon. For the accuracy of NAW detection, the computational retrieval was successful at retrieving the topper NAWs. However, this technique was more accurate in retrieving the frequency of nouns and adverbs than in measuring the frequency of verbs and adjectives. However, computational bootstrapping seems more effective in generating a customized search because the top-down approach could not retrieve as much words as required. We therefore recommend integrating both techniques for compiling dialectal lexica.

\section{Conclusion}

Frequency-based dialectal lexical are useful for building up language resources. The specificity and sensitivity of the retrieved lexica depends greatly on the adopted method of compilation. We recommend the interoperability between automatic detection of the seeding words and the psycholinguistic experimentation and validation of the generated vocabulary. We also recommend the social media streams as a rich medium for generating colloquial dictionaries. Contribution of similar studies to machine translation and to building language resources would be made. This lexicon can be integrated among other dialectal varieties of Arabic to enrich such a poorly resourced language. 


\section{References}

Alatawi, E. (2015). Structural, socio-pragmatic, and psycholinguistic analysis of codeswitching in Arabic TV programs. Doctoral dissertation, Northeastern Illinois University.

Alexeeva, S., Slioussar, N., \& Chernova, D. (2018). StimulStat: A lexical database for Russian. Behavior Research Methods, 50(6), 2305-2315. http://doi.org/10.3758/s13428-017-0994-3

Arenas, E. S. (2018). Exploring Pornography in Widad Benmoussa's Poetry Using LIWC and Corpus Tools. Sexuality \& Culture, 22(4), 1094-1111. http://doi.org/10.1007/s12119-018-9513-7

Buckwalter, T., \& Parkinson, D. (2014). A frequency dictionary of Arabic: Core vocabulary for learners. Routledge. https://doi.org/10.4324/9780203883280

Collins, P., \& Yao, X. (2018). Colloquialisation and the evolution of Australian English. English World-Wide, 39(3), 253-277. https://doi.org/10.1075/eww.00014.col

Davies, M., \& Gardner, D. (2013). A frequency dictionary of contemporary American English: Word sketches, collocates and thematic lists. Routledge. https://doi.org/10.4324/9780203880883

Essam, B. A. (2017). Compiling a lexicon of pornography using web, WordNet and Frame Net to develop an individual pornographic index. Sexuality \& Culture, 21(2), 534-548. http://doi.org/10.1007/s12119-016-9403-9.

Hanson, R. C., Rose, E., \& Little, Z. (2001). A comparative investigation of the semantic structure of language. Cross-Cultural Research, 35(3), 303-342. http://doi.org/10.1177/106939710103500303

Holes, C. (2018). Arabic Historical Dialectology: Linguistic and Sociolinguistic Approaches (Vol. 30). Oxford University Press. https://doi.org/10.1093/oso/9780198701378.001.0001

Ingham, B. (1994). Najdi Arabic: Central Arabian (Vol. 1). John Benjamins Publishing. https://doi.org/10.1075/loall.1

Ismail, S. M. (2017). Translating dialect embedded in Najdi proverbs into English. Dialectologia: Revista Electrònica, 19, 93-107.

Jorgensen, J. C. (1990). The psychological reality of word senses. Journal of Psycholinguistic Research, 19(3), 167-190. https://doi.org/10.1007/BF01077415

Mattiello, E. (2009). Difficulty of slang translation. In A. Chantler \& C. Dente (Eds.), Translation practices: through language to culture (Vol. 122). Rodopi.

McCrae, J. P., Wood, I., \& Hicks, A. (2017, June). The Colloquial WordNet: Extending Princeton WordNet with Neologisms. International Conference on Language, Data and Knowledge (pp. 194-202), Springer, Cham. https://doi.org/10.1007/978-3-319-59888-8_17

Miller, G. A., Beckwith, R., Fellbaum, C., Gross, D., \& Miller, K. J. (1990). Introduction to WordNet: An on-line lexical database. International Journal of Lexicography, 3(4), 235-244. https://doi.org/10.1093/ij1/3.4.235

Wilks, Y. (2008). Machine translation: its scope and limits. Springer Science \& Business Media.

\section{Copyrights}

Copyright for this article is retained by the author, with first publication rights granted to the journal.

This is an open-access article distributed under the terms and conditions of the Creative Commons Attribution license (http://creativecommons.org/licenses/by/4.0/). 